\title{
Release of Micronutrients from Different Substrates of Organic Matter to the Soil
}

\author{
M. Choudhury ${ }^{1 *}$, D. K. Patgiri' ${ }^{2}$, P. Ahmed ${ }^{3}$, G. K. Upamanya ${ }^{4}$, \\ R. Brahma ${ }^{3}$ and D. K. Borah ${ }^{5}$ \\ ${ }^{1}$ Department of Soil Science, ${ }^{3}$ Department of Agronomy, ${ }^{4}$ Department of Plant Pathology, SCS \\ College of Agriculture, Assam Agricultural University, Dhubri, Assam, India \\ ${ }^{2}$ Department of Soil Science, College of Agriculture, Assam Agricultural University, \\ Jorhat, Assam, India \\ ${ }^{5}$ Faculty of Agriculture, Assam Agricultural University, Jorhat, Assam, India \\ *Corresponding author
}

\section{A B S T R A C T}

An incubation experiment was conducted to study the release of micronutrients over a period of time upon addition of different substrates of organic matter to the soil. Three substrates of organic matter viz. farm yard manure (FYM), composts made from rice straw

Keywords

Micronutrients, FYM, Compost, Organic Matter

Article Info

Accepted: 10 July 2020 Available Online: 10 August 2020 (RSC) and rubber leaves (RLC) were used for the study. In each pot $6 \mathrm{~kg}$ soils from the surface layer $(0-30 \mathrm{~cm})$ under a matured rubber plantation was taken. Substrates of the organic matter at the rate of $10 \mathrm{t} \mathrm{ha}^{-1}$ was added to each pot. The moisture content was maintained at sixty per cent $(60 \%)$ water holding capacity of the soil at ambient temperature. A control was maintained throughout the experimental period. The experiment was conducted for three months and samples were collected after 7, 15, 30, 45, 60 and 90 days for analysis of various micronutrients. Results revealed variations in the rate of mineralization of the DTPA extractable micronutrients and HWS-B from different substrates of organic matter. Initial immobilizations of the DTPA-extractable micronutrient cations were observed irrespective of the substrate which was followed by gradual increase in their contents. With the incorporation of FYM, mineralization of micronutrients showed increasing trends from seven days onward and continued till the end of the experiment (90 days). Evidently addition of various substrates of organic matter resulted in building up of DTPA-extractable micronutrients and HWS-B.

\section{Introduction}

Soil organic matter serves as an important reserve for much of the available soil micronutrient (Varghese et al., 2001). Application of FYM significantly increases the plant availability of micronutrients (Vyas et al., 2003). Application of compost even if applied in low amounts, causes a significant increase in total concentration of soil micronutrients. Further, the time of application of FYM influenced the content of soil micronutrients (Thangavel et al., 2003). Application of organic amendments to agricultural soil influences metal distribution in soil fractions and results in an increase in 
all extractable micronutrients compared to soil with mineral fertilization which in turn, could influence the availability of micronutrients to plants (Dey et al., 2019). Farmers in the north-east have been applying various organic manures since time immemorial (Basumatary et al., 2000). However, information about the release of micronutrients upon addition of different micronutrients upon addition of different substrates of organic matter is scarce. Hence an attempt has been made to study the release of micronutrients upon addition of organic matters in the soil at different time interval.

\section{Materials and Methods}

An incubation experiment was conducted in completely randomised design (CRD). Soil samples were collected from the surface layer $(0-30 \mathrm{~cm})$ of a matured rubber plantation $(25$ years old). It was dried in shade, ground and processed to remove stone, decayed roots etc. A portion of the sample was collected and stored for analysis to determine the pretreatment nutrient status. Twenty four earthen pots of about $8 \mathrm{~kg}$ capacities were taken; cleaned thoroughly and sun dried.

Three substrates of organic matter viz., farm yard manure (FYM), compost made from rice straw (RSC) and compost made from rubber leaves (RLC) were used for the study. Samples were collected for determination of nutrient content of different organic manures as per standard procedure before incorporation into the soil. In each pot $6 \mathrm{~kg}$ of soil was taken and organic manures at the rate of $10 \mathrm{t} \mathrm{ha}^{-1}$ was added to it. An absolute controlled was also maintained. Moisture content was maintained at 60 percent water holding capacity at ambient temperature. The experiment was continued for three months and samples were collected after 7, 15, 30, 45, 60 and 90 days and analysed for various micronutrients as per standard procedure.

\section{Results and Discussion}

Initial characteristics of the soil, total macro and micronutrient content of the soil, composts and FYM used in the experiment are given in Table 1.

\section{DTPA-Fe}

Reduction in DTPA-Fe was observed 7 days after incorporation of various substrates of organic matter (Table 2). Reduction at 7 days was highest with RLC (13.11\%) followed by RSC $(11.63 \%)$ and FYM (8.73\%) (Table 2). It was found to be almost equal or slightly higher than the initial value at 15 days after incorporation. With RSC and RLC the highest level of DTPA-Fe was observed at 45 days after which it remained unchanged till the end of the experiment (Fig.1). However, with FYM the increasing trend of the DTPA-Fe content continued till the end of the experiment and the amount of DTPA was highest at the end of 90 days $\left(325.38 \mathrm{mg} \mathrm{kg}^{-1}\right.$, $31.69 \%$ increase over control). Jagtap et al., (2006) also observed that FYM was found to be beneficial for release of DTPA-extractable iron. Singh and Kumar (2007) recorded maximum available $\mathrm{Fe}$ content to the extent of 121.6 and $114.2 \mathrm{mg} \mathrm{kg}^{-1}$ at $15^{\text {th }}$ day and lowest of 11.7 and $8.7 \mathrm{mg} \mathrm{kg}^{-1}$ at $90^{\text {th }}$ day of incubation with organic matter in normal and Sodic soil, respectively. There was a constant average increase in Fe release from organic amendments after 50 days of incubation and the delayed release was ascribed to the formation of organic complexes of higher stability with $\mathrm{Fe}$ which were likely to be decomposed at slower rate (Dey et al., 2019)

\section{DTPA-Mn}

Fluctuations in DTPA-Mn were very high owing to the incorporation of different substrates of organic matter with soil (Fig. 2). Reduction in DTPA-Mn to the tune of 39.97 
percent was recorded 7 days after incorporation of RLC followed by 35.33 reductions resulted from RSC incorporation (Table 3). Application of FYM resulted in lesser reduction of DTPA-Mn 7 days after incorporation compared to the other sources. All the three organic substrates resulted in increased amount of DTPA-Mn. The increasing trend in DTPA-Mn was almost similar for RSC and RLC. However, for FYM the increasing trend continued till the end of the experiment. At the end of the experiment RSC, RLC and FYM resulted in increase in DTPA-Mn to the tune of 45.30, 41.59 and 56.74 percent, respectively. Shuman (1988) tried to determine the effects of organic matter on the distribution of Mn among soil fractions and found that increasing organic matter caused $\mathrm{Mn}$ to move from the less soluble forms to more plant available forms (exchangeable and organic) and oxidationreduction effects were cited as the probable mechanism of this movement. Walia et al., (2010) observed a rise in DTPA-Mn along with its increased solubility under submerged conditions and the chelating action of organic manure. Further, comparing different organic sources, application of FYM could be considered as an effective practice as it helps to add DTPA-Mn in soil.

\section{DTPA-Zn}

The content of DTPA- $\mathrm{Zn}$ recorded on $7^{\text {th }}$ day after addition of different substrates of organic matter was lower than the initial value (Fig. 3). Addition of RSC resulted in highest levels of DTPA-Zn $\left(6.68 \mathrm{mg} \mathrm{kg}^{-1}\right)$ at 45 days after the initiation of the experiment and slightly reduced afterward (Table 4). With RLC, the peak level of DTPA-Zn was observed 60 days after incubation and it was slightly less at 90 days. Even though there was initial reduction in the DTPA-Zn upon addition of FYM, it showed continuous increase till the end. Singh and Kumar (2007) studied the effect of organic amendments on zinc availability on calcareous soils and observed that the mean value of available $\mathrm{Zn}$ varied from 2.36 to $2.65 \mathrm{ppm}$ in FYM and poultry manure treatments respectively. They recorded that the content of extractable zinc decreased up to 7 days of incubation and thereafter it tended to increase. They ascribed the initial decrease in extractable $\mathrm{Zn}$ may to the immobilization by soil microorganisms. Ojha et al., (2018) found an augmentation in available $\mathrm{Fe}, \mathrm{Mn}$ and $\mathrm{Zn}$ in an incubation study with organic amendments. A continuous rise in available $\mathrm{Zn}$ was observed which was attributed to the formation of chelating complex and therefore slow mineralization rate of applied organic matter for which $\mathrm{Zn}$ became slowly available even after extraction of the element from insoluble compounds.

\section{DTPA-Cu}

Application of different substrates of organic matter resulted in decrease in DTPA-Cu as evidenced from the Fig. 4. Seven days after application of RSC, RLC and FYM, it was found to have reduced to the tune of 8.07 , 10.76 and 6.08 percent, respectively compared to the initial value (Table 5). In the RSC treated pots, the highest DTPA-Cu (13.36 $\mathrm{mg} \mathrm{kg}^{-1}$ ) was recorded 45 days after application following which it showed a declining trend. In case of RLC treated pots the highest level (13.48 $\left.\mathrm{mg} \mathrm{kg}^{-1}\right)$ of DTPA-Cu was observed 60 days after incorporation and it was almost 58 percent higher than the initial value. A steady increase in DTPA-Cu was observed in the FYM treated pots since $7^{\text {th }}$ day till the end. At the end of the experiment (90days) DTPA-Cu content was the highest in the pots treated with RLC (13.40 mg kg-1). Herencia et al., (2008) observed that application of organic amendments to agricultural soils influenced metal distribution in soil fractions and in turn influenced the 
availability of micronutrients to plants. They found that addition of compost did not cause a significant effect on the total content of the soil but resulted in an increase in all extractable $\mathrm{Cu}$ compared to soil with mineral fertilization and the oxidisable fraction was always favoured by the organic amendment. Walia et al., (2010) reported that the slight increase in the $\mathrm{Cu}$ content was notably observed in plots treated with organic manures over the control plots.

Table.1 Initial characteristics of soil, compost and manure used in the experiment

\begin{tabular}{|c|c|c|c|c|}
\hline Properties & Soil & RLC $^{*}$ & $\mathbf{R S C}^{\#}$ & $\mathbf{F Y M}^{\S}$ \\
\hline$\%$ Ash & ND & 63.4 & 61.7 & 57.9 \\
\hline pH & 5.3 & 7.15 & 7.06 & 7.72 \\
\hline$E C\left(d S ~ m^{-1}\right)$ & 0.09 & 4.6 & 4.9 & 5.3 \\
\hline $\mathrm{C}(\%)$ & 1.27 & 11.86 & 12.64 & 15.66 \\
\hline $\mathbf{N}(\%)$ & 0.113 & 1.06 & 1.19 & 0.82 \\
\hline $\mathrm{C} / \mathrm{N}$ & 11.24 & 11.19 & 10.62 & 19.1 \\
\hline \multicolumn{5}{|c|}{ Macronutrients (Total) $(\%)$} \\
\hline $\mathbf{P}$ & 0.004 & 0.49 & 0.41 & 0.52 \\
\hline $\mathbf{K}$ & 0.021 & 0.38 & 0.33 & 1.51 \\
\hline $\mathbf{C a}$ & 0.096 & 1.61 & 1.86 & 0.73 \\
\hline Mg & 0.024 & 0.34 & 0.35 & 0.38 \\
\hline \multicolumn{5}{|c|}{ Total Micronutrients (ppm) } \\
\hline $\mathbf{F e}$ & 2.47 & 9134 & 8715 & 4186 \\
\hline Mn & 483 & 157 & 241 & 52 \\
\hline $\mathbf{Z n}$ & 108.5 & 58 & 67 & 36 \\
\hline $\mathbf{C u}$ & 84.1 & 204 & 186 & 77 \\
\hline B & 14.72 & 6.4 & 5.8 & 15.3 \\
\hline
\end{tabular}

*RLC: Rubber leaf compost; \#RSC: Rice straw compost; § FYM: Farm yard manure

Table.2 Changes in DTPA-Fe during the incubation of soil with different substrates of organic matter

\begin{tabular}{|l|c|c|c|c|c|c|c|}
\hline \multirow{2}{*}{ Source } & \multicolumn{7}{|c|}{ DTPA-Fe (mg k $\mathbf{~ g}^{-\mathbf{~}}$. } \\
& Initial & 7 days & 15 days & 30 days & 45 days & 60 days & 90 days \\
\hline Control & 247.08 & 249.64 & 250.15 & 249.12 & 247.80 & 245.27 & 250.88 \\
& & $(1.04)$ & $(1.24)$ & $(0.83)$ & $(0.29)$ & $(-0.73)$ & $(1.54)$ \\
\hline RSC & 247.08 & 218.35 & 274.66 & 288.71 & 302.64 & 298.36 & 302.70 \\
& & $(-11.63)$ & $(11.16)$ & $(16.85)$ & $(22.49)$ & $(20.75)$ & $(22.51)$ \\
\hline RLC & 247.08 & 214.68 & 260.38 & 293.28 & 314.55 & 312.45 & 314.95 \\
& & $(-13.11)$ & $(5.38)$ & $(18.70)$ & $(27.31)$ & $(26.46)$ & $(27.47)$ \\
\hline FYM & 247.08 & 225.50 & 248.74 & 279.38 & 295.35 & 318.48 & 325.38 \\
& & $(-8.73)$ & $(0.67)$ & $(13.07)$ & $(19.54)$ & $(28.90)$ & $(31.69)$ \\
\hline
\end{tabular}

*Figures in parentheses indicate the percent change over the initial value 
Table.3 Changes in DTPA-Mn during the incubation of soil with different substrates of organic matter

\begin{tabular}{|l|c|c|c|c|c|c|c|}
\hline \multirow{2}{*}{ Source } & \multicolumn{7}{|c|}{ DTPA-Mn $\left(\mathbf{m g ~ k g}^{\mathbf{- 1}}\right)$} \\
\cline { 2 - 9 } & Initial & 7 days & 15 days & 30 days & 45 days & 60 days & 90 days \\
\hline Control & 33.40 & 31.82 & 33.55 & 34.26 & 33.84 & 35.51 & 34.83 \\
& & $(-4.73)$ & $(0.45)$ & $(2.57)$ & $(1.32)$ & $(6.32)$ & $(4.28)$ \\
\hline RSC & 33.40 & 21.60 & 33.90 & 43.58 & 49.05 & 48.51 & 48.53 \\
& & $(-35.33)$ & $(1.50)$ & $(30.48)$ & $(46.86)$ & $(45.24)$ & $(45.30)$ \\
\hline RLC & 33.40 & 20.05 & 33.10 & 40.09 & 47.12 & 47.34 & 47.29 \\
& & $(-39.97)$ & $(-0.90)$ & $(20.03)$ & $(41.08)$ & $(41.74)$ & $(41.59)$ \\
\hline FYM & 33.40 & 26.12 & 35.55 & 41.66 & 44.50 & 51.18 & 52.35 \\
& & $(-21.80)$ & $(6.44)$ & $(24.73)$ & $(33.23)$ & $(53.23)$ & $(56.74)$ \\
\hline
\end{tabular}

*Figures in parentheses indicate the percent change over the initial value

Table.4 Changes in DTPA-Zn during the incubation of soil with different substrates of organic matter

\begin{tabular}{|l|c|c|c|c|c|c|c|}
\hline \multirow{2}{*}{ Source } & \multicolumn{7}{|c|}{ DTPA-Zn $\left(\mathbf{m g ~ k g}^{-1}\right)$} \\
\cline { 2 - 9 } & Initial & 7 days & 15 days & 30 days & 45 days & 60 days & 90 days \\
\hline Control & 4.56 & 4.55 & 4.60 & 4.72 & 4.79 & 4.85 & 4.91 \\
& & $(-0.22)$ & $(0.88)$ & $(3.51)$ & $(5.04)$ & $(6.36)$ & $(7.68)$ \\
\hline C-Rice Straw & 4.56 & 4.05 & 4.78 & 5.56 & 6.68 & 6.74 & 6.52 \\
& & $(-11.18)$ & $(4.82)$ & $(21.93)$ & $(46.49)$ & $(47.81)$ & $(42.98)$ \\
\hline C-Rubber leaf & 4.56 & 4.20 & 4.89 & 5.40 & 6.10 & 6.38 & 6.31 \\
& & $(-7.89)$ & $(7.24)$ & $(18.42)$ & $(33.77)$ & $(39.91)$ & $(38.38)$ \\
\hline FYM & 4.56 & 4.33 & 5.08 & 5.25 & 5.48 & 5.74 & 5.98 \\
& & $(-5.04)$ & $(11.40)$ & $(15.13)$ & $(20.18)$ & $(25.88)$ & $(31.14)$ \\
\hline
\end{tabular}

*Figures in parentheses indicate the percent change over the initial value

Table.5 Changes in DTPA-Cu during the incubation of soil with different substrates of organic matter

\begin{tabular}{|l|c|c|c|c|c|c|c|}
\hline \multirow{2}{*}{ Source } & \multicolumn{7}{|c|}{ DTPA-Cu (mg kg-1 } \\
\cline { 2 - 9 } & Initial & 7 days & 15 days & 30 days & 45 days & 60 days & 90 days \\
\hline Control & 8.55 & 8.51 & 8.60 & 8.84 & 9.06 & 9.08 & 9.12 \\
& & $(-0.47)$ & $(0.58)$ & $(3.39)$ & $(5.96)$ & $(6.20)$ & $(6.67)$ \\
\hline C-Rice Straw & 8.55 & 7.86 & 9.37 & 12.05 & 13.36 & 13.17 & 13.09 \\
& & $(-8.07)$ & $(9.59)$ & $(40.94)$ & $(56.26)$ & $(54.04)$ & $(53.10)$ \\
\hline C-Rubber leaf & 8.55 & 7.63 & 9.56 & 12.35 & 13.07 & 13.48 & 13.40 \\
& & $(-10.76)$ & $(11.81)$ & $(44.44)$ & $(52.87)$ & $(57.66)$ & $(56.73)$ \\
\hline FYM & 8.55 & 8.03 & 9.12 & 11.00 & 11.42 & 12.08 & 12.35 \\
& & $(-6.08)$ & $(6.67)$ & $(28.65)$ & $(33.57)$ & $(41.29)$ & $(44.44)$ \\
\hline
\end{tabular}

*Figures in parentheses indicate the percent change over the initial value 
Table.6 Changes in HWS-B during the incubation of soil with different substrates of organic matter

\begin{tabular}{|l|c|c|c|c|c|c|c|}
\hline \multirow{2}{*}{ Source } & \multicolumn{7}{|c|}{ HWS-B (mg kg $\mathbf{~}^{-\mathbf{1}}$ ) } \\
\cline { 2 - 9 } & Initial & 7 days & 15 days & 30 days & 45 days & 60 days & 90 days \\
\hline Control & 0.38 & 0.39 & 0.41 & 0.40 & 0.37 & 0.38 & 0.39 \\
& & $(2.63)$ & $(7.89)$ & $(5.26)$ & $(-2.63)$ & $(0.00)$ & $(2.63)$ \\
\hline C-Rice Straw & 0.38 & 0.44 & 0.59 & 0.66 & 0.68 & 0.71 & 0.72 \\
& & $(15.79)$ & $(55.26)$ & $(73.68)$ & $(78.95)$ & $(86.84)$ & $(89.47)$ \\
\hline C-Rubber leaf & 0.38 & 0.48 & 0.53 & 0.59 & 0.65 & 0.64 & 0.66 \\
& & $(26.32)$ & $(39.47)$ & $(55.26)$ & $(71.05)$ & $(68.42)$ & $(73.68)$ \\
\hline FYM & 0.38 & 0.41 & 0.54 & 0.62 & 0.71 & 0.75 & 0.77 \\
& & $(7.89)$ & $(42.11)$ & $(63.16)$ & $(86.84)$ & $(97.37)$ & $(102.63)$ \\
\hline
\end{tabular}

*Figures in parentheses indicate the percent change over the initial value

Fig.1 Changes in DTPA-Fe content of soil incubated with various substrates of organic matter

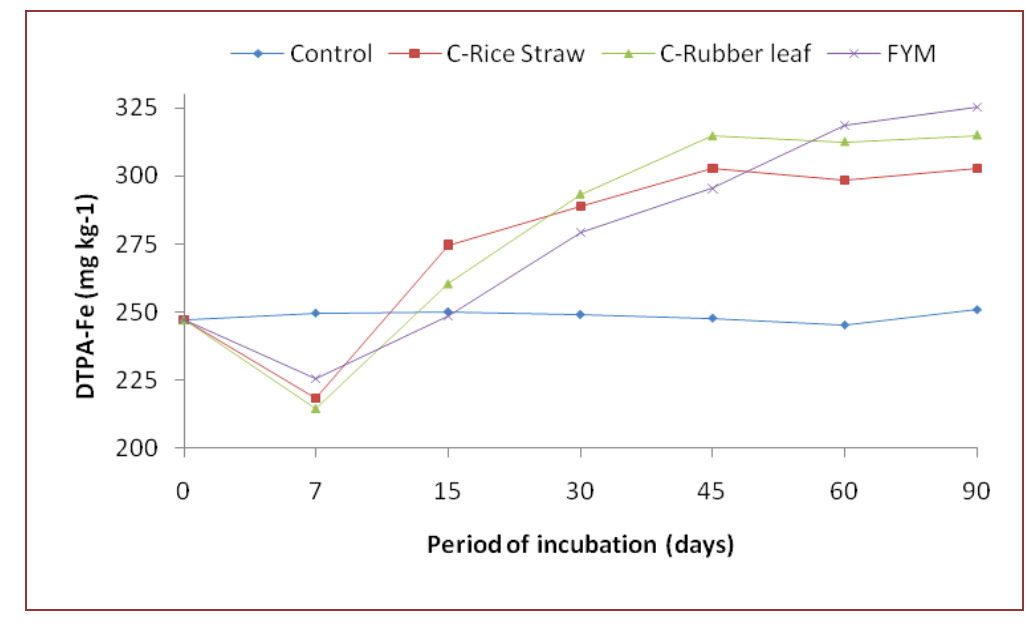

Fig.2 Changes in DTPA-Mn content of soil incubated with various substrates of organic matter




Fig.3 Changes in DTPA-Zn content of soil incubated with various substrates of organic matter

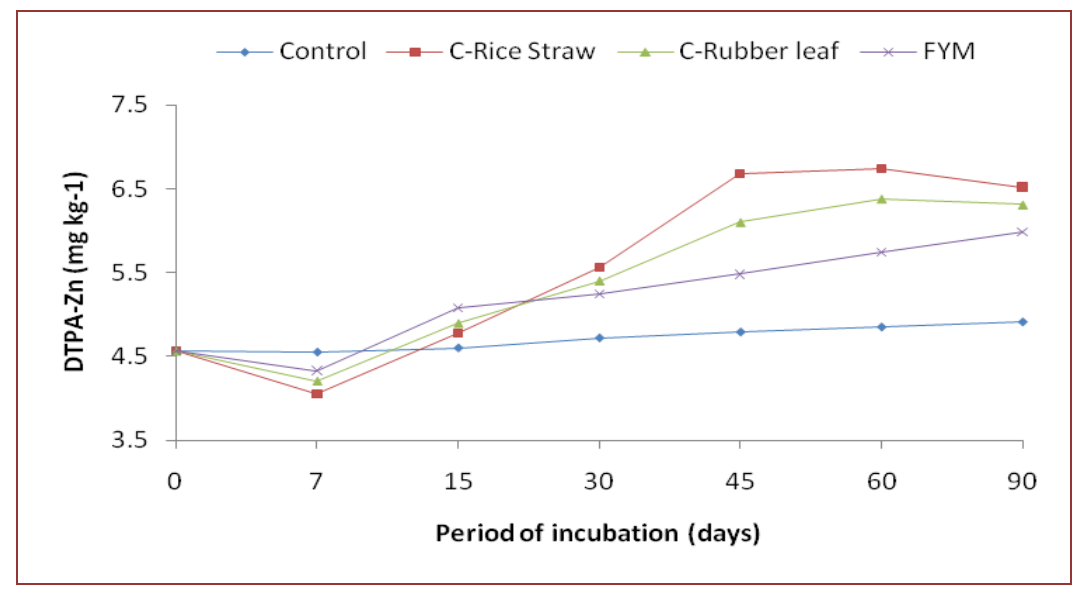

Fig.4 Changes in DTPA-Cu content of soil incubated with various substrates of organic matter

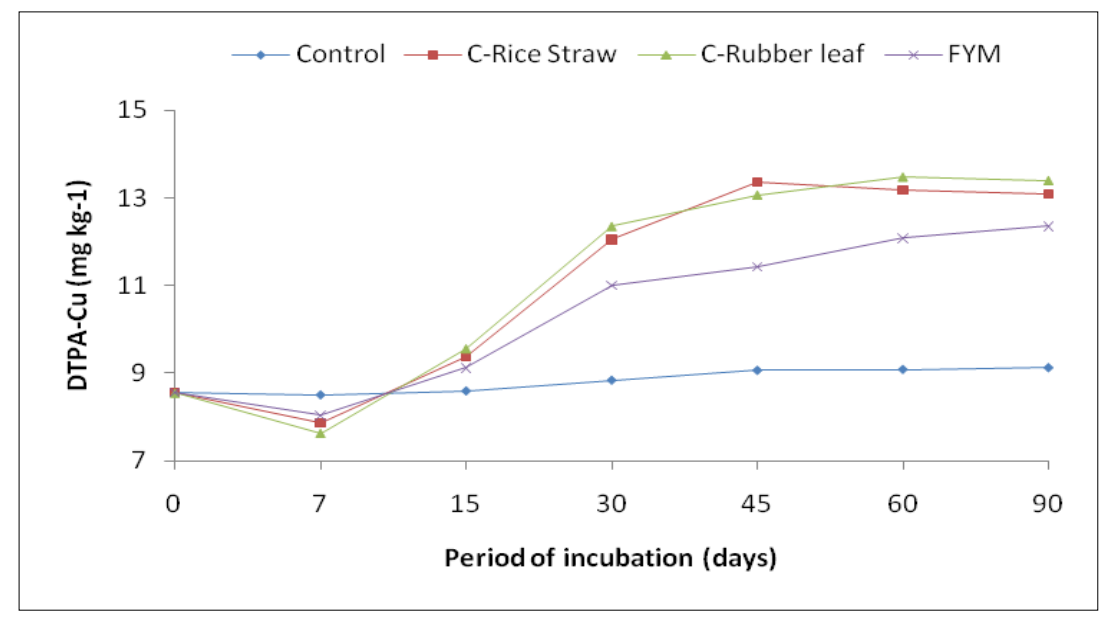

Fig.5 Changes in HWS-B content of soil incubated with various substrates of organic matter

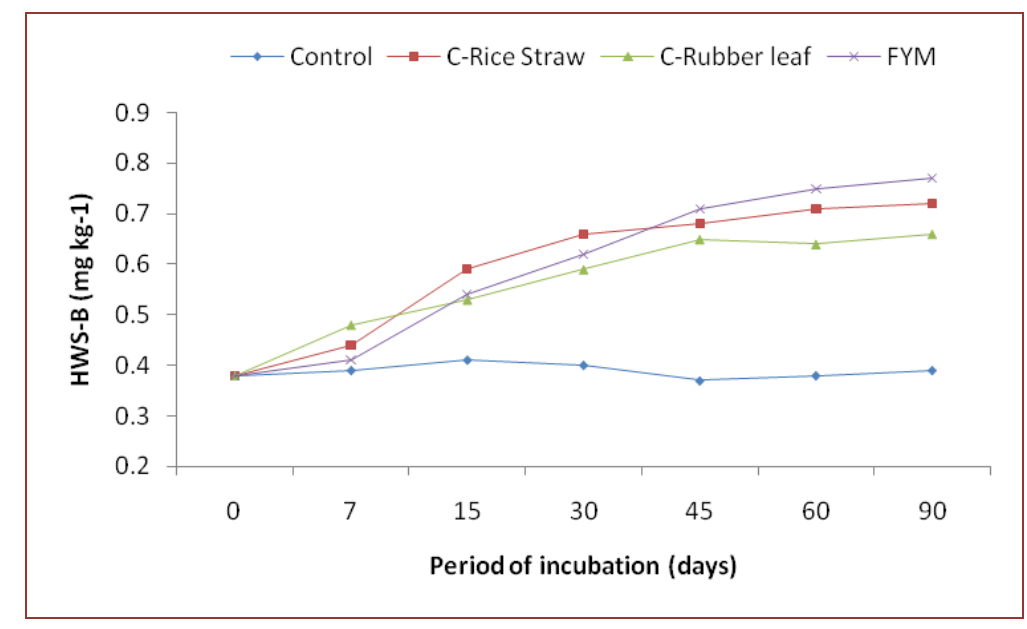


The adding of FYM, green manure (GM) and wheat cut straw (WCS) results in greater micronutrients release in available forms in the soil as compared with chemical fertilization alone. Organic manure addition lowers the soil redox-potential which eventually increase the available $\mathrm{Cu}$ in soil. Increment of DTPA-Cu might be associated with the chelating action of organic compounds that are liberated due to decomposition of FYM, GM and WCS that helps in availability of micronutrients through the prevention of some processes like fixation, oxidation, precipitation and leaching.

\section{HWS-B}

Application of different substrates of organic matter resulted in steady increase in HWS-B in the soil during the entire incubation period (Fig. 5). Initial (7 days) increase in HWS-B was the highest with RLC (26.32\%). RSC resulted the highest increment in HWS-B at $15(55.26 \%)$ and $30(73.68 \%)$ days after incubation (Table 6). However, from 45 days onward FYM produced the highest increment in it till the end of the experiment. It was observed that at the end of the incubation different substrates viz. RSC, RLC and FYM resulted 89.47, 73.68 and 102.63 percent increase in HWS-B over the initial value. Saha et al., (1998) observed significant and positive correlation between organic matter and HWS-B. They stated that boron formed strong diol-complexes with organic matter which were available to plants and contributed positively to B extracted by hot water.

In conclusion the soil organic matter serves as an important reserve for much of the available soil micronutrient and application of different substrates of organic matter significantly increased the DTPA extractable and HWS-B in soils. Increased availability of micronutrients owing to the addition of organic matter has been clearly evident from the study. Application of FYM and compost prepared from rice straw and rubber leaf caused a noticeable increase in available micronutrient cations and HWS-B in soil at the end of the experiment, though a slight reduction was observed initially. Hence, it can be safely concluded that application of organic matter to soils may increase the availability of micronutrients to plants and over a comfortably long period of time.

\section{References}

Basumatary, A., Talukdar, M. C. and Das, J. 2000. Long term effect of integrated nutrients supply on DTPA-extractable micronutrients in an Inceptisols of Assam. New Agriculturist, 11(1, 2): 7779.

Dey, A., Srivastava, P. C., Pachauri, S. P., Shukla, A. K. 2019. Time dependent release of some plant nutrients from different organic amendments in a laboratory study. Int. J. recycl. org. waste Agric. (Supl. 1): 5173-5188

Herencia, J. F., Ruiz, J. C., Morillo, E., Melero, S., Villaverde, J. and Maqueda, C. 2008. The effect of organic and mineral fertilization on micronutrient availability in soil. Soil Sci. 173(1): 6980.

Jagtap, P. B., Patil, J. D., Nimbalkar, C. A. and Kadlag, A. D. 2007. Influence of integrated management on soil properties and release of nutrients in a saline-sodic soil. J Indian Soc. Soil Sci. 55(2): 147-156.

Ojha, S., Sourabh, S., Dasgupta, S., Das, D. K. and Sarkar, A. 2018. Influence of different organic amendments on Fe, $\mathrm{Mn}, \mathrm{Cu}$ and $\mathrm{Zn}$ availability in Indian soils. Int. J. Curr. Microbiol. App.Sci. 7(05): 2435-2445.

Saha, J. K., Singh, M. V. and Sharma, B. L. 1998. Available status of boron in 
major soil groups of Madhya Pradesh. J Indian Soc. Soil Sci. 46(3): 478-79.

Shuman, L. M. 1988. Effect of organic matter on the distribution of manganese, copper, iron and zinc in soil fractions. Soil Sci. 146: 192-98.

Singh, B. and Kumar, S. 2007. Availability of $\mathrm{Fe}$ as influenced by organic matter and moisture regime in normal and sodic soils. Indian J. Agric. Chem. 40(1): 2934.

Thangavel, P., Balagurunathan, R. and Prabakaran, J. 2003. Nutrient dynamics of the tamarind leaf litter composted with various inoculants. Indian J. Ecol. 30(1): 117-120.

Varghese, M., Sharama, A. C. and Pothen, J. 2001. Addition of litter, its decomposition and nutrient release in rubber plantations in Tripura. Indian $\mathrm{J}$. Nat. Rubb. Res., 14(2): 116-124.

Vyas, M. D., Jain, A. K. and Tiwari, R. J. 2003. Long-term effect of micronutrients and FYM on yield of and uptake by soybean on a Typic Chromustert. J Indian Soc. Soil Sci. 51(1): 45-47.

Walia, M. K., Walia, S. S. and Dhalliwal, S. S. 2010. Long term effect of integrated nutrient management on properties of Typic Ustochrept after 23 cycles of irrigated rice (Oryza sativa L.) - wheat (Triticum aestivum L.) system. J. Sustain. Agric. 34:724-743.

\section{How to cite this article:}

Choudhury, M., D. K. Patgiri, P. Ahmed, G. K. Upamanya, R. Brahma and Borah, D. K. 2020. Release of Micronutrients from Different Substrates of Organic Matter to the Soil. Int.J.Curr.Microbiol.App.Sci. 9(08): 175-183. doi: https://doi.org/10.20546/ijcmas.2020.908.019 